\title{
Selected Adsorbents for Removal of Contaminants from Wastewater: Towards Engineering Clay Minerals
}

\author{
Kalebaila K. Kennedy*, Kenneth J. Maseka, Misheck Mbulo \\ School of Mathematics and Natural Sciences, Department of Chemistry, Copperbelt University, Kitwe, Zambia \\ Email: ${ }^{\star} k$ kalebai@gmail.com
}

How to cite this paper: Kennedy, K.K., Maseka, K.J. and Mbulo, M. (2018) Selected Adsorbents for Removal of Contaminants from Wastewater: Towards Engineering Clay Minerals. Open Journal of Applied Sciences, 8, 355-369

https://doi.org/10.4236/ojapps.2018.88027

Received: June 10, 2018

Accepted: August 28, 2018

Published: August 31, 2018

Copyright $\odot 2018$ by authors and Scientific Research Publishing Inc. This work is licensed under the Creative Commons Attribution International License (CC BY 4.0).

http://creativecommons.org/licenses/by/4.0/

\begin{abstract}
The provision and demand for safe water continues to be a major aspect for governments worldwide as the population continues to grow accompanied by an increase in anthropogenic activities that contaminate water bodies. The common contaminants are the negatively charged ions such as sulfates, positive ions like heavy metals and organic molecules like dyes and phenols. Although, various methods exist for purification of wastewater, the adsorption process is a low cost method that uses readily available adsorbents. Activated carbon, although costly for developing countries, is still the most efficient adsorbent for a variety of substances. However, low cost adsorbents derived from biowaste have being actively explored in water purification. Photocatalytic nanostructured adsorbents not only play a bifunctional role in adsorbing contaminants but also are able to decompose organic pollutants in water using sunlight. The engineering of naturally abundant clay in most developing countries offers an even inexpensive way to clean-up wastewater.
\end{abstract}

\section{Keywords}

Adsorption, Wastewater, Heavy Metals, Organic Pollutants, Activated Carbon, Clay, Nanoadsorbent, Photocatalysis

\section{Introduction}

Water is an important natural resource for human, animal, plant and aquatic life on earth and any contamination of it has considerable negative impacts on the environment. Unfortunately, industrialization and a boom in the world population have lead to a severe compromise in the integrity of water resource due to 
unchecked disposal of wastewater from these activities. Mining, agricultural, pharmaceutical and textile industrial activities accidentally or deliberately introduce a variety of inorganic and organic pollutants into water systems changing the quality of water system that ecological life depends on [1] [2] [3] [4]. In addition sewage contamination of water occurs from raw sewage overflow, leaking sewer lines or partially treated waste water. Excess rain or bust of sewer lines consequently leads to dumping of sewage in flowing river systems and/or underground water points [5]. In developing countries with poor water treatment processes and rural areas, the sewage pollution of water is a major cause of water-borne diseases such as cholera, typhoid and dysentery.

In order to mitigate water pollutants, several methods such as filtration, solvent extraction, ion exchange, chemical oxidation and precipitation, coagulation, floatation, sedimentation and membrane process are used [6]. The success of each method is hampered by the inherent shortfall for each method. For instance, in chemical oxidation, the use of chlorine causes unavoidable side products and metal corrosion of the oxidation tower units. In filtration, although only small space and low pressures are needed, the energy demand is very high [7] [8]. In lieu of the above methods, adsorption process, a well-known method for large-scale gas separation and industrial catalysis, has over the years garned momenta towards mitigation of polluted water.

Adsorption materials are thermally stable and easy to prepare while the adsorption process is simple to design and operate. In addition, the process does not produce redundant side-products and the solid materials can be regenerated by thermal desorption [9]. Adsorption is a process when a material, the adsorbate (being adsorbed), builds-up either on the surface of a material or accumulates within the pores of the solid material (the adsorbent). The interaction of the adsorbate and the adsorbent can occur by either physical or chemical forces. In physical adsorption (physisorption) the dominant forces of interaction are the Van der Waals forces; in contrast, chemisorption involves interaction of the adsorbent with adsorbate by chemical forces as shown in Figure 1. Generally, adsorbents are high surface area and porous materials used in catalysis, molecular separation, and gas storage. The pore sizes range from $2-5 \mathrm{~nm}$ for micropores, 5 - $50 \mathrm{~nm}$ for mesopores and $50-100 \mathrm{~nm}$ for macropores. The high surface areas allows for a large number of the adsorptive to be trapped or stuck on the adsorbate. Further, the high porosity ensures facile mass transfer of materials within the pores i.e. faster kinetics for the removal of pollutants.

\section{Types of Adsorbents}

Natural adsorbents such as coal, zeolites, clay, and wood and have been used in removal of cations, dyes, and organic compounds from wastewater as reviewed in [10]. These adsorbents exist in abundant supply and offer a cheap and constant supply of raw material. However, the cost associated with the processing of these adsorbents limits wide-scale application in developing countries. Agriculture 


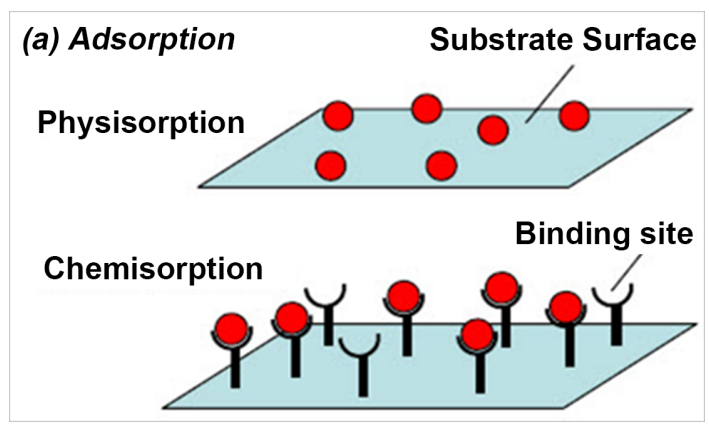

Figure 1. (a) Depiction of physisorption and chemisorption interaction between the substrate surface (adsorbent) and the adsorbate molecules (Adapted from https://hub.globalccsinstitute.com/publications/co2-capt ure-technologies-post-combustion-capture-pcc/adsorpti on).

waste such as shells and peels from fruits as well as industrial waste like fly ash and bottom ash are another source of cheaper and readily available adsorbents for waste-water treatment [11]. Another review in [12] draws attention to a variety of adsorbents such as agricultural waste products, biomass based activated carbon, natural clay, metal oxide nanomaterials; nitrides of boron as well such carbon based adsorbents have been used in waste-water treatment. The amount of adsorbed pollutants generally increases with $\mathrm{pH}$, contact time, agitation rate as well as an increase in temperature and the adsorbent dose. In most cases, the choice of a suitable adsorbent will depend on cost consideration.

Although, extensive research has been conducted on adsorbents in water treatment, this article highlights application of selected adsorbents in removal of undesirable compounds from water by the adsorption process. Activated carbon offers superior adsorption associated with its structural integrity and from these properties other selected adsorbents discussed here have been engineered to improve adsorption capacity. For a developing country like Zambia and particularly the Copperbelt Province where there is lots of production of heavy metals from copper mining activities, the development and use of low cost farm-waste and locally abundant clay would be advantageous in the treatment of mine water tailings. Additionally, most rivers in Zambia are continuously choked by the unchecked discharge of effluent from sewers, fertilizers leading to overgrowth of algae that cokes fresh water systems [13]. The engineering of locally abundant clay to not only adsorbed but photo-decompose algae would be productive.

\section{Engineered Natural Adsorbents}

\subsection{Activated Carbon}

Activated carbons (AC) are non-polar solids prepared by activation and calcination of materials rich in carbon such as animal, plant, or mineral origin into activated carbon. A review by Mohammad-Khah and Ansari [14] provides greater details on the preparation and characterization of activated carbon from a varie- 
ty of organic sources like are wood, charcoal, nut shells, coals, bone paper-waste, and synthetic polymers. The authors have indicated that AC can be made by physical or chemical activation depending on the source of the raw material and the desired texture of the AC. The physical activation method is often employed because it's easy and requires less handling of the material. In this process, the raw material is initially carbonized at $450^{\circ} \mathrm{C}$ to eliminate the bulk of the volatile matter. Then the carbon is heated in the presence of either carbon dioxide or steam at $900^{\circ} \mathrm{C}$ or with air at low temperature.

In general, $\mathrm{AC}$ is the bench-mark adsorbent to which other adsorbents are compared. AC shows very high surface areas up to $2000 \mathrm{~g} / \mathrm{m}^{2}$ and has high internal porosity which is desirable parameters for adsorption and retention of undesired matter inorganic, biological and organic waste from wastewater. Because of the different pore sizes, different sizes of molecular pollutants can be filtered out by adsorption to the carbon surface (Figure 2). Granular activated carbon (GAC) and powdered activated carbon (PAC) are commonly used in water treatment with GAC having a large particle size compared to PAC. Spent activated carbon can be regenerated by annealing to drive off adsorbent waste and recycled in the filtration process.

One major disadvantage of $\mathrm{AC}$ is the low adsorption capacity for metal ions due to the hydrophobic nature of AC. To overcome this deficiency, AC is chemically modified with chelating groups and/or polar groups to increase the binding effect with cations [14] [15]. Although PAC is often used due to a low initial cost, it becomes costly in operational processes and is very difficult to regenerate. On the other hand, GAC has a huge start-up cost but can be utilized over a long period of time with little maintenance and spent GAC can be regenerated [16] [17].

\section{Applications in Water Treatment}

Activated carbons are widely used in removal of organic pollutants and heavy metals from wastewater. In the removal of various organic compounds, it has been suggested that using activated carbon with oxygen surfaces is suitable from removing polar organic pollutants. Whilst, using activated carbon deficient of surface oxygen's is suitable for removing non-polar organic compounds. Activated carbon has been widely used to remove dyes and a variety of phenol containing molecules from waste water. It is postulated that the oxygen groups on the carbon surface interact with the aromatic ring of the organic groups via a complex donor-acceptor mechanism [10].

Dyes are known carcinogenic and are hard to decompose by bacteria in water as well as being photo-stable and resistant to natural oxidation. Physical adsorption using activated carbon has been shown to successfully remove different dyes in wastewaters originating from textile and paper industries. In a 2013 review, wood bottom ash and fly ash were used to remove dyes such as Congo red and methylene blue. Furthermore, activated carbon and wood charcoal were reported to remove $98 \%$ and $90 \%$ phenol from water, respectively. Activated 


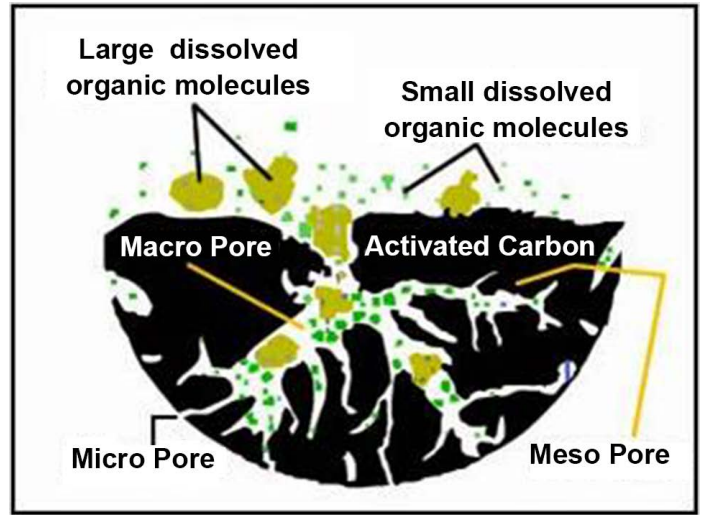

Figure 2. Physical morphology of activated carbon matrix. Source:

http://biomassproject.blogspot.com/2017/02/activatedcarbon-production-from.html.

carbon is also used to remove heavy metals but the degree of adsorption varies depending on the nature of the activated carbon. Since activated carbon is hydrophobic, the efficiency of removing metal ions from aqueous (water) medium is very poor.

To improve the adsorption of solution heavy metal salts, the hydrophobic surface of active carbon is pretreated with chelating groups that will anchor the metal ions from wastewater. Several metal ions such as $\mathrm{Ni}^{2+}, \mathrm{Co}^{2+}, \mathrm{Cd}^{2+}, \mathrm{Cu}^{2+}$, $\mathrm{Pb}^{2+}, \mathrm{Cr}^{2+}$ have been show to adsorb on $\mathrm{AC}$ as a function of $\mathrm{pH}$ of the water. In one case carcinogenic $\mathrm{Cr}^{6+}$ ion could only be removed under acidic conditions [10] [11] [18].

\subsection{Clay and Kaolin}

Natural clays are attractive adsorbents being low cost and abundant in the earth, with very high internal surface area and high porosities. The structure of clay is composed of numerous tetrahedral and octahedral layers of $\mathrm{Si}, \mathrm{Al}, \mathrm{Mg}$ and layers of oxygen, hydroxyl groups, respectively (Figure 3). These layers are separated by pockets of interlayer space with either positively charged (excess $\mathrm{Si}, \mathrm{Al}$, or $\mathrm{Mg}$ ) or negatively charged (excess oxygen, hydroxyl) dangling surface groups. The interlayer spacing's are prime for adsorption of unwanted cations, anions or other molecules from contaminated water. The adsorption capacity of clay depends on the degree of the charges on the clay surface as well as the ions balancing the excess charges. The clays can adsorb a range of compounds such as pesticides, herbicides, pathogens and inorganic $\mathrm{SO}_{4}^{2-}, \mathrm{PO}_{4}^{3-}$, and $\mathrm{NO}_{3}^{-}$anions and heavy metals cations [19].

Grassi et al. (2012) and Gupta et al. (2009) reported a number of different types of clay exist but montmorillonite, bentonite and kaolinite have been used often in removal of organic species from water. The major differences lies in the percentage composition of $\mathrm{Al}_{2} \mathrm{O}$ and $\mathrm{SiO}_{2}$ layers in each type of clay as shown in Table 1. Montmorillonite contains the surface with the lowest positive charge 


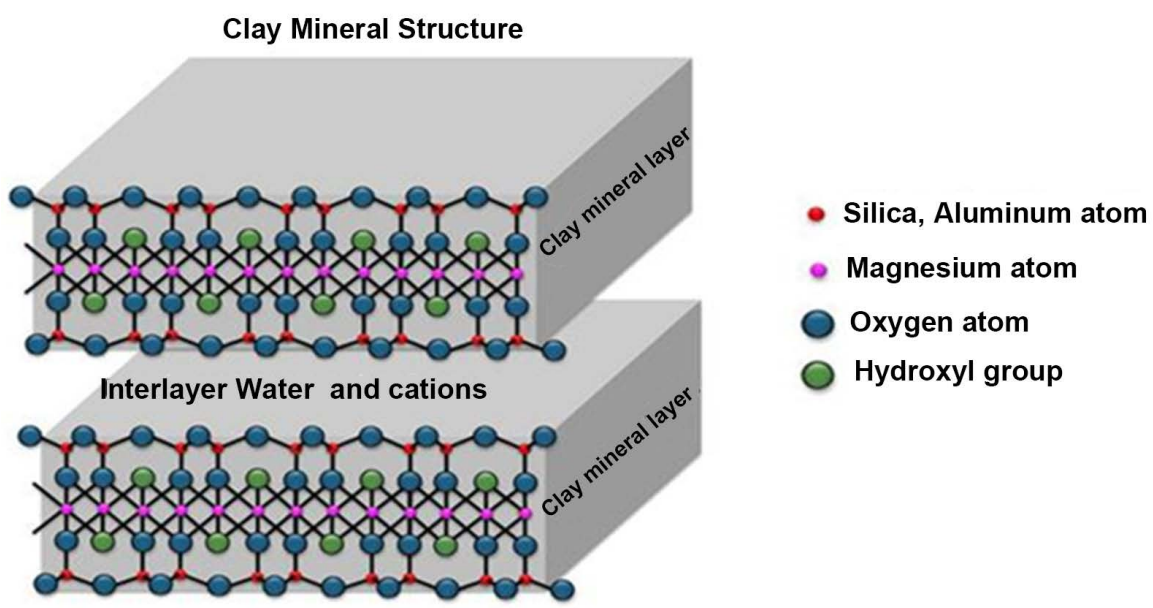

Figure 3. Typical structure of natural clay (image adapted from https://www.jpl.nasa.gov/spaceimages/details.php?id=PIA17598.

Table 1. Ratio of alumina and silica in the selected clays*.

\begin{tabular}{ccc}
\hline Clay Type & $\% \mathrm{Al}_{2} \mathrm{O}_{3}$ & $\% \mathrm{SiO}_{2}$ \\
\hline Montmorillonite & 19 & 44 \\
Bentonite & 33 & 54 \\
Kaolinite & 40 & 47 \\
\hline
\end{tabular}

*http://webmineral.com/.

while kaolinite has the highest positive surface with excess $\mathrm{Al}^{3+}$ units. Bentonite has an overall net charge because the $\mathrm{Al}^{3+}$ are substituted by $\mathrm{Fe}^{2+}$ or $\mathrm{Mg}^{+2}$ in the octahedral sites while the $\mathrm{Si}^{4+}$ are substituted by $\mathrm{Al}^{3+}$ in the tetrahedral sites [20] [21].

\section{Applications in Water Treatment}

The investigation of montmorillonite, bentonite and kaolinite in waste water treatment has been reported. Syafalni and coworkers observed that bentonite was a good adsorbent for removal of organic matter as evidenced by removal of about 75\% chemical oxygen demand (COD) under acidic conditions. The authors further noted that a combination of bentonite with limestone improved the adsorption capacity of the composite bentonite [22]. An investigation by Banat et al. showed limited potential of removal of phenol dye using bentonite and the adsorption capacity for phenol increased with a decrease in the $\mathrm{pH}$ [23]. Other researchers investigated removal of amoxicillin antibiotic from water using bentonite and observed like others, that the adsorption of the antibiotic increased with a decrease in $\mathrm{pH}$. About $88 \%$ of the drug was removed and this was compared with activated carbon, although AC adsorption was much faster having a very high surface area compared to the clay [24].

Gupta and Bhattacharyya reported the potential of kaolinite, montmorillonite and the acid-active forms to remove divalent $\mathrm{Cd}$ and $\mathrm{Pb}$ ions from spiked water. 
They observed that montmorillonite was better at retaining the cations compared to kaolinite and for both clays the adsorption capacity increased after acid activation [25]. Hascakir and Dolgen used kaolinite to test the removal of organic matter determined by measuring the COD parameter. They noted that up to $80 \%$ organic matter was removed when kaolinite was used as a flocculant and alum as a coagulant. In the case of industrial wastewater, 96\% COD removal was achieved by using only kaolinite as a coagulant [26].

\subsection{Farm-Waste as Adsorbents}

A detailed review article by Bhatnagar and Sillanpää [27] and De Gisi et al. [28] shows a variety of farm waste products ranging from shells, husk, fruits, to stems, coconuts, mangos and bananas peels. A common feature is the existence of a variety of functional groups such as the hydroxyl groups inherent in the chemical composition of the waste capable of binding pollutants in water. The waste is often physically or chemically modified to enhance the adsorption capacity by increasing the surface area and reactive surface groups. As described in Acharya et al. [29] chemical modification of farm-waste adsorbents helps to get rid of soluble organic compounds, thus enhancing the chelating effect especially needed for metal adsorption. The abundance of agriculture waste around offers a readily available raw material that can be used to purify water even to a small extent.

\section{Applications in Water Treatment}

Low cost organic waste from farming activities in the removal of heavy metals and dyes from wastewater for poor and remote communities reported. Mallampatia and Valiyaveettil studied the use of tomato peels in extraction of $\mathrm{Pb}^{2+}, \mathrm{Ni}^{2+}$, $\mathrm{As}^{3+}$ and $\mathrm{Cr}^{6+}$, dyes and pesticides from water. They reported that tomato peels could efficiently adsorb cationic dyes and metal cations such as $\mathrm{Pb}^{2+}$ and $\mathrm{Ni}^{2+}$. The adsorption mechanism was attributed to the electrostatic interaction between $\mathrm{OH}^{-}$and $\mathrm{HCOO}^{-}$functional groups present on the surface of the peels and the positive adsorbents [30].

Mittal and coworkers used de-oiled soya extracts and bottom ash (heavier ash that does not rise on coal combustion) to remove methyl orange from aqueous solutions. The de-oiled soya extracts had higher adsorption capacities at $16.664 \mathrm{mg} / \mathrm{g}$ compared to the bottom ash at $3.618 \mathrm{mg} / \mathrm{g}$. The bottom ash and de-oiled-soya soaked up to $98.61 \%$ and $99.8 \%$, respectively before needing regeneration. In both cases, up to $98 \%$ of the adsorbents could be regenerated using a simple wash of the columns with sodium hydroxide [31].

Bhatnagar and colleagues studied the effectiveness of lemon peels to remove heavy metals from wastewater using column stacks. They observed that $1 \mathrm{~kg}$ of lemon peels could remove cobalt ions from $210 \mathrm{~L}$ of synthetic wastewater before the adsorbent (lemon peels) reached saturation. The adsorption capacity was $22 \mathrm{mg} / \mathrm{g}$. From a cost point of view, they concluded that it would be cheaper to use these low cost organic waste peels than the 10 times expensive activated carbon in treating waste water for heavy metals [32]. 


\section{Nanostructured Adsorbents and Photocatalysts}

\subsection{Metal Oxide-Based Nanoadsorbents}

Nanostructured materials are display unique properties compared to their bulk counterparts by having at least one dimension of the structural geometry on the nanoscale order of $1-100 \mathrm{~nm}$. The nanoscale properties impact small particle sizes that translate into very high surface areas with a large number of surface active sites. The surface edges have a high density of unsaturated atoms that increases adsorption and degradation of pollutants in water [33]. Although the adsorption process for water quality improvement has garnered incredible improvements due to ease of operation and readily available low cost adsorbents, the need for a "super" adsorbent i.e. one with a high degree of adsorption and ease of separation is on-going. Over the years, researchers have focused on developing this "super" adsorbent based on nanostructured materials for the exclusion of water pollutants.

The 2014 review by Ali et al. showed that oxides and hydroxides of iron, sulfides of zinc and cadmium, oxides of titanium, zinc and copper nanoparticles have been successful on the bench-scale and pilot-scale to adsorb pollutants from water. In the case of iron based nanoparticles, separation of the spent nanoparticles from water is easily achieved by applying a magnetic field [6]. Another review by Hua and colleagues gives a detailed account of the removal of heavy metal removal from wastewater using various nanosized metal oxides such as $\mathrm{ZnO}, \mathrm{Al}_{2} \mathrm{O}_{3}, \mathrm{MnO}, \mathrm{TiO}_{2}, \mathrm{MgO}, \mathrm{CeO}_{2}$, and $\mathrm{Fe}_{2} \mathrm{O}_{3}$ [34]. Titanium dioxide $\left(\mathrm{TiO}_{2}\right)$ and alumina $\left(\mathrm{Al}_{2} \mathrm{O}_{3}\right)$ nanostructured particles have shown considerable potential in mitigating water contamination. Alumina nanoparticles were efficient in removing heavy metal pollutants such as $\mathrm{Cr}, \mathrm{Cd}, \mathrm{Pb}$ and $\mathrm{Hg}$ ions from aqueous solutions [35]. The adsorption mechanism was postulated to involve the anchoring of the positive metallic ions on the active oxide/hydroxyl sites on the high surface area alumina [36].

\subsection{Carbon-Based Nanoadsorbents}

A review by Burakov et al. [18] and by Shah et al. [37] describes the use of nanostructured carbon materials such as carbon nanotubes, fullerenes $\left(\mathrm{C}_{60}\right)$ and graphene in the removal of heavy metals form waste water discharges. The ability of these materials to adsorb contaminants is due to the high strength surfaces as well as the thermal stability that allows for regeneration of the spent adsorbent. In addition, chemical modification of these adsorbents by anchoring polar functional groups such as hydroxides $\left(\mathrm{OH}^{-}\right)$and carboxyl's $\left({ }^{-} \mathrm{COOH}\right)$ greatly enhances the adsorption properties towards a variety of contaminants in water.

Valcarcel et al. [38] recognized that surface defects on fullerenes are the primary sites for adsorption when the contaminants enter the cage through spaces between the carbon nanoclusters. A study by Alekseeva et al. [39] showed that $\mathrm{Cu}^{2+}$ ions can be removed from water with an adsorption capacity of $14.6 \mathrm{mmol} / \mathrm{g}$. Large-scale use of fullerenes is limited due to the prohibitive cost of fullerenes, 
therefore small amounts of fullerenes are doped into adsorbents such as activated carbons. Samonin et al. [40] showed that doping up to $0.004 \%$ of fullerenes into activated carbon increased the adsorption capacity for $\mathrm{Pb}^{2+}$ and $\mathrm{Cu}^{2+}$ by up to 2.5 times more.

Carbon nanotubes and graphene oxide have been used in removal of organic compounds and heavy metals from water. Wang et al. [41] increased the oxygen functional groups on multi-walled carbon nanotubes (CNT) by acidification and reported significant adsorption of $\mathrm{Pb}^{2+}$ ions by complexation on the CNT surface. Zhao et al. [42] modified CNT adsorbents by doping with $\mathrm{TiO}_{2}$ and $\mathrm{MnO}_{2}$, respectively, to remove $\mathrm{Pb}^{2+}$, where the composite material had adsorption capacities of $137 \mathrm{mg} / \mathrm{g}$ and $78.74 \mathrm{mg} / \mathrm{g}$, respectively. Other researchers have impregnated graphene oxide with magnetic particles for adsorption of $\mathrm{Pb}^{2+}$ and $\mathrm{Cd}^{2+}$ where the adsorption was $\mathrm{pH}$ dependent.

Although, the carbon based nanoadsorbents have the mechanical rigidity and potential for effective adsorption when appropriately modified, large-scale use is limited by the cost of these carbonaceous adsorbents. Shah et al. [37] emphasizes that synthetic methods of carbon adsorbents are still complicated; agglomeration of the adsorbents in aqueous phase decreases the adsorption affinity; and the toxicity of the materials to the ecosystem has not been exhaustively investigated.

\subsection{Nanoadsorbent Photocatalysts}

$\mathrm{TiO}_{2}$ nanoparticles are eco-friendly, abundant and have emerged as promising candidates in environmental remediation including water treatment. $\mathrm{TiO}_{2}$ nanoparticles can have dual functionality as adsorbents and photocatalysts. The $\mathrm{TiO}_{2}$ will not only adsorb but are capable of photo-oxidation of organic adsorbates. $\mathrm{TiO}_{2}$ (anatase form) is a UV semiconductor with a band-gap energy of $3.2 \mathrm{eV}$. Since solar energy consists of $4 \% \mathrm{UV}$ light, $\mathrm{TiO}_{2}$ is often doped with either non-metals or transition-metal ions to enable absorption of visible light which constitutes $\sim 45 \%$ of solar energy [43]. Additionally, $\mathrm{TiO}_{2}$ is often incorporated into high surface area matrices such as silica $\left(\mathrm{SiO}_{2}\right)$ to ensure a high degree of adsorption of pollutants in addition to the actual photocatalytic degradation reactions. When $\mathrm{TiO}_{2}$ is irradiated with light, electron-hole pairs are formed that when in contact with air forms superoxides $\left(\mathrm{O}_{2}^{-}\right)$and hydroxyl radicals $(\mathrm{OH})$. These radicals can partially or completely mineralize a variety of adsorbed organic molecules into benign products such as carbon dioxide, water, and inorganic ions as depicted in Figure 4.

It has been reported that after 8 hours of simulated solar radiation, $\mathrm{TiO}_{2}$ nanoparticles reduced the capability of waterborne pathogens such as protozoa, fungi, and a complete inactivation of fecal coliforms using natural sunlight [44] [45]. A review by Amin and others gives detailed summary in which various researchers have improved the efficiency of $\mathrm{TiO}_{2}$ by doping to achieve visible light photocatalysis. In one instance, silver doped $\mathrm{TiO}_{2}$ had almost complete obliteration of the E. coli bacteria under irradiation [46]. 
Conduction band

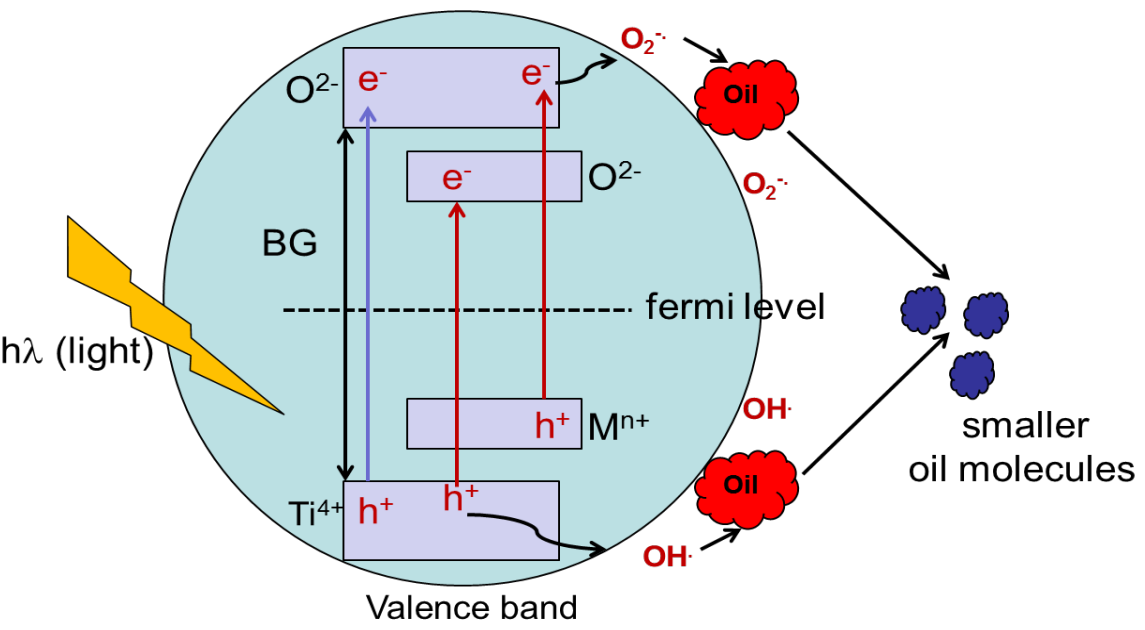

Figure 4. Adsorption and decomposition of organic molecules on $\mathrm{TiO}_{2}$ photocatalyst by radicals.

$\mathrm{TiO}_{2}$-zeolite composites were used to study the UV photodecomposition of naphthenic acid (components in oil streams that are toxic and corrosive to machinery). The initial concentration of the acid and $\mathrm{CO}_{2}$ in gas phase were followed by GC-MS (Figure 5). Over 3 days, the concentration of the acid declined appreciably while the abundance of $\mathrm{CO}_{2}$ (composition product) increased to over $93 \%$ (Figure 6). Meanwhile, the acid content had declined to amounts difficult to detect in the gaseous form. The total acidity the acid decreased by $31 \%$ compared to mixtures not exposed to UV light as determined by Tan (Total Acid Number) [47].

\section{Conclusions and Perspectives}

Among the various technologies for water purification, the adsorption process is a cost effective method for water remediation. The process requires good adsorbents with high adsorption capacities, low cost maintenance in terms of production and regeneration. Additionally, activated carbon remains the mostly used adsorbent due to the ability to remove a variety of pollutants from water. But the high costs of activated charcoal production and regeneration on a large scale become prohibitive in less economically developed nations.

Research has engaged a variety of alternative and cheaper adsorbents to reduce water contaminants. Nanomaterial adsorbents continue to be an exciting field of research for now and the foreseeable future. However, a large scale implementation needs adequate knowledge of the potential hazardous of the nanomaterials on the ecosystem. An exciting field of research to develop in developing countries is the use of the locally abundant natural clays to serve as photocatalytic adsorbents. Since clays are non-conductors, engineering these clays would transform for them into UV and visible photocatalysts similar to the treatment of $\mathrm{TiO}_{2}$ nanoparticles. These materials would not only serve as 


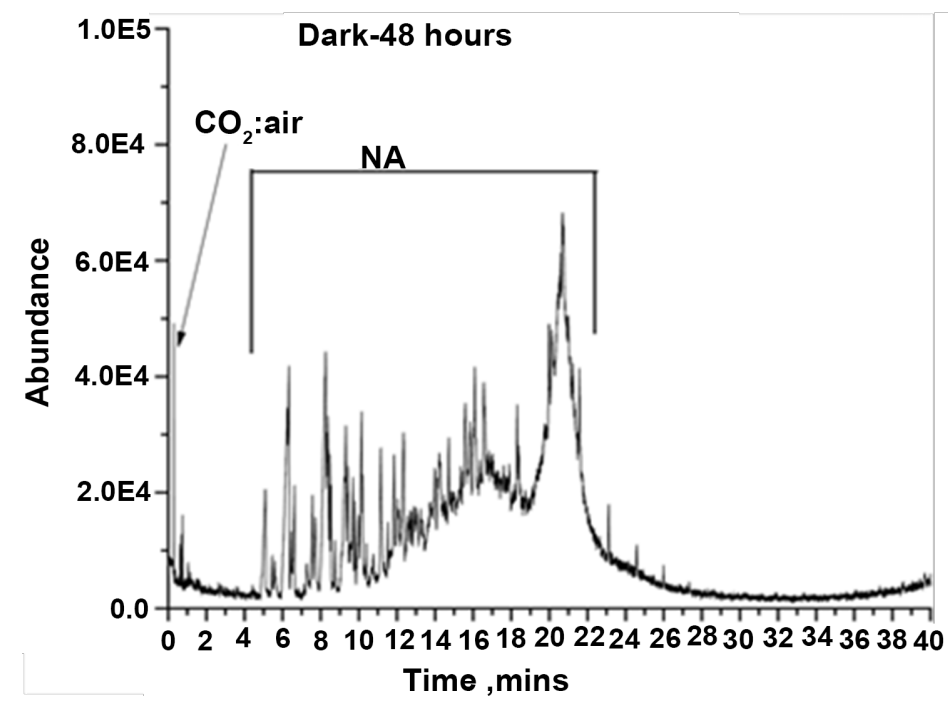

Figure 5. GC-MS analysis of head-space aliquots from UV photocatalysis of naphthenic acid by of $\mathrm{Z}^{-\mathrm{TiO}_{2}}$ after 48 hours. Adapted from (Kalebaila and Fairbridge, 2014).

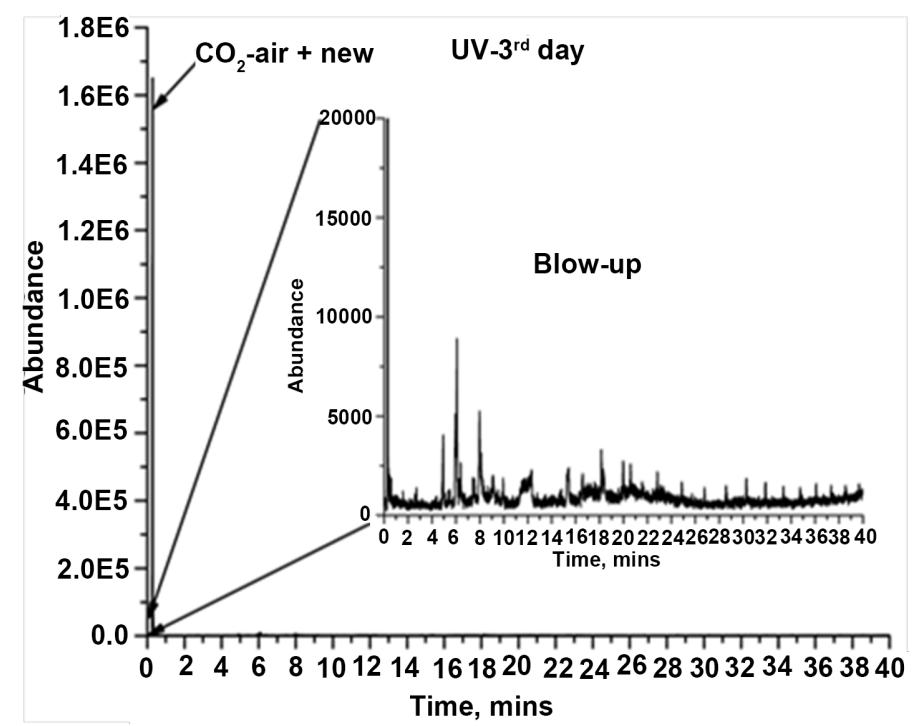

Figure 6. GC-MS analysis of head-space aliquots from UV photocatalysis of naphthenic acid by of $\mathrm{Z}-\mathrm{TiO}_{2}$ after 3 days. Adapted from (Kalebaila and Fairbridge, 2014).

adsorbents, as well as photocatalysts by modifying the clay with inorganic ions using the sol-gel synthetic process. Substituting some of the $\mathrm{Al}_{2} \mathrm{O}_{3}$ and $\mathrm{SiO}_{2}$ in the clay with transition metals would allow for this transformation. The modified clay would serve a dual function as adsorbent (mop up) and photodecomposer (eat up) of contaminants.

\section{Conflicts of Interest}

The authors declare no conflicts of interest regarding the publication of this paper. 


\section{References}

[1] Solomon, W. (1995) Environmental Impact of Metals Derived from Mining Activities: Processes, Predictions, Prevention. Journal of Geochemical Exploration, 52, 5-23. https://doi.org/10.1016/0375-6742(94)00039-E

[2] Ikenaka, Y., Nakayama, S.M.M., Muzandu, K., Choongo, K., Teraoka, H., Mizuno N. and Ishizuka, M. (2010) Heavy Metal Contamination of Soil and Sediment in Zambia. African Journal of Environmental Science and Technology, 4, 729-739.

[3] Harrad, S. (2001) Persistent Organic pollutants, Environmental Behaviour and Path Ways for Human Exposure. Kluwer Academic Publishers, Norwell.

[4] Kümmerer, K. (2009) The Presence of Pharmaceuticals in the Environment Due to the Human Use. Journal of Environmental Management, 90, 2354-2366. https://doi.org/10.1016/j.jenvman.2009.01.023

[5] Pedersen, T. (1997) Contamination of Water and Soil by Sewage and Water Treatment Sludge. http://extoxnet.orst.edu/faqs/safedrink/sewage.htm

[6] Ali, M.E., Ullahb, M. and Hamid, S.B.A. (2014) Conventional to Nano-Green Adsorbents for Water Pollution Management: A Review. Advanced Materials Research, 925, 674-678. https://doi.org/10.4028/www.scientific.net/AMR.925.674

[7] Barakat, M. (2011) New Trends in Removing Heavy Metals from Industrial Wastewater. Arabian Journal of Chemistry, 4, 361-377.

https://doi.org/10.1016/j.arabjc.2010.07.019

[8] Gupta, V.K. and Suhas (2009) Application of Low-Cost Adsorbents for Dye Removal-A Review. Journal of Environmental Management, 90, 2313-2342.

https://doi.org/10.1016/j.jenvman.2008.11.017

[9] Grassi, M., Kaykioglu, G., Belgiorno, V. and Lofrano, G. (2012) Removal of Emerging Contaminants from Water and Wastewater by Adsorption Process. In: Lofrano, G., Ed., Emerging Compounds Removal from Wastewater, Springer, Dordrecht, 15-37. https://doi.org/10.1007/978-94-007-3916-1_2

[10] Bhatnagar, A. and Minocha, A. (2006) Conventional and Non-Conventional Adsorbents for Removal of Pollutants from Water. Indian Journal of Chemical Technology, 13, 203-217.

[11] Bisht, R., Agarwal, M. and Singh, K. (2016) Heavy Metal Removal from Wastewater Using Various Adsorbents: A Review. Journal of Water Reuse and Desalination, 7, 387-419.

[12] Singh, N., Nagpal, G., Agrawal, S. and Rachna (2018) Water Purification by Using Adsorbents: A Review. Environmental Technology and Innovation, 11, 187-240. https://doi.org/10.1016/j.eti.2018.05.006

[13] Sibanda, N. (2007) ENVIRONMENT-ZAMBIA: Efforts to Halt the Strangulation of Kafue. Inter Press Service.

http://www.ipsnews.net/2007/08/environment-zambia-efforts-to-halt-the-strangula tion-of-kafue/

[14] Mohammad-Khah, A. and Ansari, R. (2009) Activated Charcoal: Preparation, Characterization and Applications: A Review Article. International Journal of ChemTech Research, 1, 859-869.

[15] Gomez-Serrano, V., Macias-Garcia, A. and Espinosa-Mansilla, A. (1998) Adsorption of $\mathrm{Hg}^{2+}, \mathrm{Cd}^{2+}$ and $\mathrm{Pb}^{2+}$ from Aqueous Solution on Heat-Treated and Sulphurized Activated Carbon. Water Resource, 32, 1-4.

[16] System, E.I. Difference between PAC and GAC. 
http://www.envis.org/technology/water-treatment/687-difference-between-pac-and $\underline{-g a c}$

[17] Lakdawala, M. and Lakdawala, J. (2013) Comparative Study of Effect of PAC and GAC on Removal of COD Contributing Component of Sugar Industry Waste Water. Research Journal of Recent Sciences, 2, 90-97.

[18] Burakov, A., Galunin, E., urakova, I., Kucherova, A., Agarwal, S., Tkachev, A. and Gupta, V. (2018) Adsorption of Heavy Metals on Conventional and Nanostructured Materials for Wastewater Treatment Purposes: A Review. Ecotoxicology and Environmental Safety, 148, 702-712. https://doi.org/10.1016/j.ecoenv.2017.11.034

[19] Savic, I., Stojiljkovic, S.I.S.I. and Gajic, D. (2014) Industrial Application of Clays and Clay Minerals. In: Clays and Clay Minerals. Geological Origin, Geological Origin, Geological Origin, Mechanical Properties and Industrial Applications, Nova Science Publishres, New York, 379-402.

[20] Ozcan, S.A. and Ozcan, A. (2004) Adsorption of Acid Dyes from Aqueous Solutions onto Acid-Activated Bentonite. Journal of Colloid and Interface Science, 276, 39-46. https://doi.org/10.1016/j.jcis.2004.03.043

[21] Onal, M. and Sarıkaya, Y. (2007) Preparation and Characterization of Acid-Activated Bentonite Powders. Powder Technology, 172, 14-18. https://doi.org/10.1016/j.powtec.2006.10.034

[22] Syafalni, R.A., Abustan, I. and Ibrahim, A.N.M. (2013) Wastewater Treatment Using Bentonite, the Combinations of Bentonite-Zeolite, Bentonite-Alum, and Bentonitelimestone-Limestone. International Journal of Environmental Sciences, 4, 379-391.

[23] Banat, F., Al-Bashir, B., Al-Asheh, S. and Hayajneh, O. (2009) Adsorption of Phenol by Bentonite. Environmental Pollution, 107, 391-398. https://doi.org/10.1016/S0269-7491(99)00173-6

[24] Putra, E., Pranowo, R., Sunarso, J., Indraswati, N. and Ismadji, S. (2009) Performance of Activated Carbon and Bentonite for Adsorption of Amoxicillin from Wastewater: Mechanisms, Isotherms and Kinetics. Water Resource, 43, 2419-2430.

[25] Gupta, S. and Bhattacharyya, K. (2009) Treamnet of Water Contaminated by $\mathrm{Pb}$ (II) and Cd(II) by Adsorption on Kaolinite, Montmorillonite and Their Acid-Activated Forms. Indian Journal of Chemical Technology, 16, 457-470.

[26] Hascakir, B. and Dolgen, D. (2008) Utilization of Clay Minerals in Wastewater Treatment: Organic Matter Removal with Kaolinite. Ekoloji, 17, 47-54. https://doi.org/10.5053/ekoloji.2008.666

[27] Bhatnagar, A. and Sillanpää, M. (2010) Utilization of Agro-Industrial and Municipal Waste Materials as Potential Adsorbents for Water Treatment-A Review. The Chemical Engineering Journal, 157, 277-296. https://doi.org/10.1016/j.cej.2010.01.007

[28] De Gis, S., Giusy Lofrano, G., Grassi, M. and Notarnicola, M. (2016) Characteristics and Adsorption Capacities of Low-Cost Sorbents for Wastewater Treatment: A Review. Sustainable Materials and Technologies, 9, 10-140. https://doi.org/10.1016/j.susmat.2016.06.002

[29] Acharya, J., Kuma, U. and Mahammed Rafi, P. (2018) Removal of Heavy Metal Ions from Wastewater by Chemically Modified Agricultural Waste Material as Potential Adsorbent-A Review. International Journal of Current Engineering and Technology, 8, 526-530. https://doi.org/10.14741/ijcet/v.8.3.6

[30] Mallampatia, R. and Valiyaveettil, S. (2012) Application of Tomato Peels as an Effi- 
cient Adsorbent for Water Purification-Alternative Biotenology? RSC Advances, 2, 9914-9920. https://doi.org/10.1039/c2ra21108d

[31] Mittal, A., Malyiya, A., Kaur, D., Mittal, J. and Kurup, L. (2007) Studies on the Adsorption Kinetics and Isotherms for the Removal and Recovery of Methyl Orange from Wastewaters Using Waste Materials. Journal of Hazardous Materials, 148, 229-240. https://doi.org/10.1016/j.jhazmat.2007.02.028

[32] Bhatnagar, A., Minocha, A. and Sillanpää, M. (2010) Adsorptive Removal of Cobalt from Aqueous Solution by Utilizing Lemon Peel as Biosorbent. Biochemical Engineering Journal, 48, 181-186. https://doi.org/10.1016/j.bej.2009.10.005

[33] Sánchez, A., Recillas, S., Font, X., Casals, E., González, E. and Puntes, V. (2011) Ecotoxicity of, and Remediation with, Engineered Inorganic Nanoparticles in the Environment. Trends in Analytical Chemistry, 30, 507-516. https://doi.org/10.1016/j.trac.2010.11.011

[34] Hua, M., Zhang, S., Pan, B., Zhang, W., Lv, L. and Zhang, Q. (2012) Heavy Metal Removal from Water/Wastewater by Nanosized Metal Oxides: A Review. Journal of Hazardous Materials, 211-212, 318-327. https://doi.org/10.1016/j.jhazmat.2011.10.016

[35] Pacheco, S. and Rodriguez, R. (2001) Adsorption Properties of Metal Ions Using Alumina Nanoparticles in Aqueous and Alcoholic Solution. Journal of Sol-Gel Science and Technology, 20, 263-273. https://doi.org/10.1023/A:1008774018992

[36] Charlet, L., Schindler, P., Spadini, L., Furrer, G. and Zysset, M. (1993) Cation Adsorption on Oxides and Clays: The Aluminum Case. Aquatic Science, 55, 291-303. https://doi.org/10.1007/BF00877274

[37] Shan, S., Zhao, Y., Tang, H. and Cui, F. (2017) A Mini-Review of Carbonaceous Nanomaterials for Removal of Contaminants from Wastewater. IOP Conference Series. Earth and Environmental Science, 68, Article ID: 012003. https://doi.org/10.1088/1755-1315/68/1/012003

[38] Valcárcel, M.M., Cárdenas, S., Simonet, B., Moliner-Martínez, Y. and Lucena, R. (2008) Carbon Nanostructures as Sorbent Materials in Analytical Processes. Trends in Analytical Chemistry, 27, 34-43. https://doi.org/10.1016/j.trac.2007.10.012

[39] Alekseeva, O., Bagrovskaya, N. and Noskov, A. (2016) Sorption of Heavy Metal Ions by Fullerene and Polystyrene/Fullerene Film Compositions. Protection of Metals and Physical Chemistry of Surfaces, 52, 443-447. https://doi.org/10.1134/S2070205116030035

[40] Samonin, V., Nikonova, V. and Podvyaznikov, M. (2014) Sorption Properties of Activated Carbon with Respect to Metal Ions. Protection of Metals, 44, 190-192. https://doi.org/10.1134/S0033173208020148

[41] Wang, H., Zhou, A., Peng, F., Yu, H. and Chen, L. (2007) Adsorption Characteristic of Acidified Carbon Nanotubes for Heavy Metal $\mathrm{Pb}(\mathrm{II})$ in Aqueous Solution. Materials Science and Engineering A, 466, 201-206. https://doi.org/10.1016/j.msea.2007.02.097

[42] Zhao, X., Jia, Q., Song, N., Zhou, W. and Li, Y. (2010) Adsorption of Pb(II) from an Aqueous Solution by Titanium Dioxide/Carbon Nanotube Nanocomposites: Kinetics, Thermodynamics, and Isotherms. Journal of Chemical and Enginering Data, 55, 4428-4433. https://doi.org/10.1021/je100586r

[43] Kalebaila, K.K. and Klabunde, J.K. (2010) An Inorganic Oxide $\mathrm{TiO}_{2}-\mathrm{SiO}_{2}-\mathrm{Mn}$ Aerogel for Visible-Light Induced Air Purification. In: American Chemical Society, Ed., Nanoscale Materials in Chemistry. Environmental Applications, 207-223. https://doi.org/10.1021/bk-2010-1045.ch012 
[44] Lonnen, J., Kilvington, S., Kehoe, S., Al-Touati, F. and McGuigan, K. (2005) Solar and Photocatalytic Disinfection of Protozoan, Fungal and Bacterial Microbes in Drinking Water. Water Research, 39, 877-883.

https://doi.org/10.1016/j.watres.2004.11.023

[45] Gelover, S., Gomez, L.A., Reyes, K. and Teresa Leal, M. (2006) A Practical Demonstration of Water Disinfection Using $\mathrm{TiO}_{2}$ Films and Sunlight. Water Research, 40, 3274-3280. https://doi.org/10.1016/j.watres.2006.07.006

[46] Amin, M., Alazba, A. and Manzoor, U. (2014) Removal of Pollutants from Water/Wastewater Using Different Types of Nanomaterials. Advances in Materials Science and Engineering, 2014, Article ID: 825910.

https://doi.org/10.1155/2014/825910

[47] Kalebaila, K. and Fairbridge, C. (2014) UV Photocatalytic Degradation of Commercial Naphthenic Acid Using $\mathrm{TiO}_{2}$-Zeolite Composites. Journal of Water Resource and Protection, 6, 1198-1206. https://doi.org/10.4236/jwarp.2014.612109 